marital state, he insists that the sole bond must be that deep affection which may be a concomitant of desire, and is the cause and justification of monogamy. Finally, he pleads for frankness towards children in matters of sex, and asserts that those who do receive this from parents obviously fond of them, and not strained in their personal relationship, are most likely to grow up healthily and happily. The greater freedom for experiment which he demands that society introduce into the convention of the family is well supported by his argument. The paper is naturally controversial, but it would benefit by the suppression of the sentimental note which is occasionally apparent.

\section{King's College (London) Engineering Society}

THE "King's Engineer", the annual of the Engineering Society and the Engineering Branch of the Old Students' Association of King's College, London, which has recently been published, is one of the most interesting publications of its kind and affords evidence of the engineering activity of the College. Fourteen papers were read by the members of the Engineering Society during the year, and four of these are reprinted in the annual. The paper on the "Development of High-Speed Compression Ignition Engines", by V. H. F. Hopkins, was the prize essay. Another paper of considerable interest is that by A. H. Jenkins on "China-Clay and China-Clay Mining in the West of England". The number is issued as a memorial volume to Prof. Ernest Wilson, who for more than thirty years was professor of electrical engineering, and who endeared himself to all King's College students. Prof. G. Cook gives an appreciation of Prof. Wilson's work, and a list of his papers.

\section{Survey of India}

THE Survey of India has published its report on map publication and office work for the year ending March 31, 1931 (Calcutta, 1932. 1 rupee). The most important part of the publication is the series of index maps of all the maps of India, including the 'Million Map' sheets. Practically the whole of India, but not Burma, and also Afghanistan, Baluchistan and Persia now appear on the useful southern Asia series of one in two million, while the greater part of India is also published on the one to a million scale of the Carte Internationale du Monde. The larger scale maps make good progress and some two hundred new sheets on different scales have been published during the year.

\section{Electric Supra-Conduction in Metals}

Prof. J. C. McLennan writes as follows: "It is regrettable that in my article on 'Supra-Conduction in Metals' published as a supplement to Nature of December 10, there were two undetected typist's errors that should have been corrected. In the third section of the article the words 'copper sulphate' should read 'copper sulphide' and in the last section the words 'wire lattice' should read 'ionic lattice'. It may be of interest to state here, too, that Prof. R. de L. Kronig's paper on the electron lattice theory of supra-conduction in metals appeared in the Zeitschrift für Physik, Bd. 78, Heft. 11 and 12."

\section{Announcements}

THE annual meeting of the British Association will be held next year in Leicester on September 6-13 under the presidency of Sir F. Gowland Hopkins, president of the Royal Society. The following sectional presidents have been appointed : Section A (Mathematical and Physical Sciences), Sir Gilbert Walker; B (Chemistry), Prof. R. Robinson; C (Geology), Prof. W. G. Fearnsides; D (Zoology), Dr. J. Gray; E (Geography), the Right Hon. Lord Meston; F (Economic Science and Statistics), Prof. J. H. Jones; G (Engineering), Mr. R. W. Allen; H (Anthropology), the Right Hon. Lord Raglan; I (Physiology), Prof. E. D. Adrian; J (Psychology), Prof. F. Aveling; K (Botany), Prof. F. E. Lloyd; L (Educational Science), Mr. J. L. Holland; M (Agriculture), Dr. A Lauder.

Mr. J. Bernard Cat.kin, Wychwood School, Bournemouth, states that in his letter entitled "Implements from the Raised Beach at Slindon Park, Sussex" (NATURE, Nov. 26, p. 813) the reference "to the Cannon shot gravels as being of interglacial age was an oversight. As they are actually a glacial deposit, I conclude that most of the Slindon beach belongs to the preceding interglacial period."

IN commemoration of the seventieth birthday of Sir P. C. Rây, founder, foundation-president and patron of the Indian Chemical Society, a jubilee volume, of some 350 pages, is being published by the Society, containing contributions from many eminent chemists in India and abroad. Orders for the volume should be sent to the Honorary Secretary, Indian Chemical Society, P.O. Box 10857, Calcutta.

Applicatrons are invited for the following appointments, on or before the dates mentioned:-A head of the Chemistry Department of the Municipal Technical College of Kingston-upon-Hull-The Director of Education, Education Offices, Guildhall, Hull (Dec. 31). A librarian and keeper of records in the Department of Antiquities, Palestine-The Director of Recruitment (Colonial Service), 2, Richmond Terrace, Whitehall, London, S.W.1 (Dec. 31). An examiner in domestic science and assistant examiners in mathematics, chemistry and other subjects for the School Certificate Examination for 1933 of the Central Welsh Board-The Clerk to the Central Welsh Board, Cardiff (Jan. 14). A head of the Civil and Mechanical Engineering Department at the Northampton Polytechnic Institute, St. John Street, London, E.C.1-The Principal (Jan. 20). A professor of experimental physics at the Queen's University of Belfast-The Secretary (March 18). A professor of zoology at the University of LeedsThe Registrar. A secretary to the Society for Cultural Relations between Great Britain and the U.S.S.R.The Chairman, S.C.R., 1, Montague Street, London, W.C.1. 